The Inscription on the Peshawar Vase.

On p. 714 Dr. Fleet says that it does not follow that in popular records of this class we must always restore double consonants up to the full standard of literary productions. I would point out that even this caveat is unnecessary for the Prakrits of the North-West. The Pissāca dialects and the neighbouring tertiary Prakrits (Sindhi and Lahndā) do not as a rule lengthen a vowel before a simplified double consonant. Thus sindhi has bhatu (not bhätu), rice, from bhattō, bhaktas; modern Paisiāai uth (not üth), a camel, from utthō, uṣtras (see J.R.A.S., 1904, p. 730). Forms like rachita-, Takhasilä-, pratithāvita- are hence perfectly regular in the North-West. The preservation of $r$ in the $b h r$ of bhrätarêthi is also typical of these North-Western dialects.

Camberley.

G. A. Grierson.

August 1st, 1906.

The negative $a$ with a finite verb in Sanskrit.

To p. 722 of the Journal, July, 1906.

Kătyāyana, in a Vārttika to Pāṇini VI, 3, 73, says:

नजो नलोपे $s$ वनेपे तिज्युपसंख्यानम् ॥ १ ॥

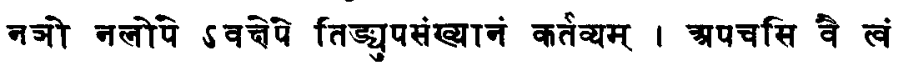
जाल्म। च्रकरोषि वे त्वं जाल्म ॥

i.e., when a reproach is to be expressed one can say: "Surely, you rogue, you cannot cook a bit! You cannot work a bit!"

This is nothing more than a vulgurism.

Th. Aufrecht.

\title{
The Origln of 'Sabaio.'
}

With reference to the last part of Mr. Beveridge's note supra (pp. 705-6), I would offer the following remarks:Downloaded from https://www.cambridge.org/core. University of Warwick, on 22 May 2018 at 01:21:30, subject to the Cambridge Core terms of use, available at https://www.cambridge.org/core/terms. 